\title{
Changes in the characteristics of dissolved organic matter released from sediment according to precipitation in the Namhan River, South Korea.
}

Haeseong Oh

Ewha Womans University

Jung Hyun Choi ( $\square$ jchoi@ewha.ac.kr)

Ewha Womans University https://orcid.org/0000-0003-0884-696X

\section{Research Article}

Keywords: Dissolved organic matter (DOM), release rate, sediment, sediment-water interface, fluorescence analysis, optical properties

Posted Date: February 25th, 2022

DOI: https://doi.org/10.21203/rs.3.rs-1302124/v1

License: (c) This work is licensed under a Creative Commons Attribution 4.0 International License.

Read Full License 


\section{Abstract}

In this study, changes in the properties of dissolved organic matter (DOM) released from sediments into water layers were investigated. To analyze the spatial and temporal variation in dissolved organic carbon (DOC), sediment and bottom water samples were collected upstream of the Gangcheon, Yeoju and Ipo weirs of the Namhan River during the rainy and non-rainy seasons. Vials containing the sediment and bottom water samples were incubated for seven days at $20^{\circ} \mathrm{C}$ in the dark. Thereafter, the DOC concentration of the supernatant was analyzed at 0, 3 and 7 days of incubation. The results show that the change of bottom water DOC concentration resulted from the DOC released from the sediments. The initial DOC was significantly correlated with precipitation $(p=0.0042)$ and residence time $(p=0.0473)$. Furthermore, fluorescence analysis revealed that the DOM contained a significant quantity of hydrophilic and low-molecular-weight (LMW) organic matter in non-rainy season, and higher levels of hydrophobic and high-molecular-weight (HMW) organic matter were observed during the rainy season.

\section{Introduction}

DOM is an important source of carbon for rivers (Panton et al., 2020; Fovet et al., 2020). As the main energy source for microbial activity, DOM can effect on ecological and biogeochemical processes in rivers (Meyer et al., 1987; Toming et al., 2013; Tranvik, 1992). The role of DOM in biogeochemical and ecological processes depends on its source, composition, the physicochemical conditions of the river, and the biological community (Andrilli et al., 2019; Mineau et al., 2016). DOM is classified into autochthonous and allochthonous depending on the source and composition. Autochthonous DOM is produced in the water body by phytoplankton, zooplankton and a mixture of living and dead bacteria (Ask et al., 2009, Devesa-Rey and Barral, 2012). It mainly consists of non-humic substances that are labile and easily degraded by microorganisms (Thurman 1985; Toming et al., 2013). Allochthonous is originated from leaves, eroded soils from terrestrial, and organic wastes of anthropogenic origin, such as organic fertilizers, wastewaters, and industrial effluents (Ramos et al., 2006). Allochthonous DOM usually consists humic substances with high molecular weight and lignin content, and it has the possibility to accumulate in sediments more than autochthonous components (Devesa-Rey and Barral, 2012; Thurman 1985).

The quantity and quality of sediment DOM can be affected by anthropogenic activities. The watershed characteristics and the hydrologic alteration resulting from the construction of weirs have impacts on the sedimentation rates and the quantity and quality of DOM buried in the sediment. Since the sediment DOM can be released into the overlying water through resuspension, erosion, and disturbance (Lee et al., 2015), the river with weir-impoundment may potentially raise water quality issues arising from the continuous release of DOM from sediments. Especially, since the increase of DOM have been closely associated with disinfection by-product (DBP) formation potentials (Yu et al., 2003), it is essential to obtain additional insight into the dynamics of sediment DOM in such weir-impounded river. The concentration and composition of DOM that is released from the sediment can vary depending on the environmental factors of the sediment and water layer, such as particle size, temperature and DO 
concentration of water, nutrient content of the sediment, pore-water and water, and hydrological characteristics (Leenheer \& Croue, 2003; Shin et al., 2016). As DOM movement from sediments to water layer results from a combination of various mechanisms, it is difficult to identify the environmental factors that predominantly contribute to this process (Hakanson \& Jansson, 1983).

In particular, rainfall, among other environmental factors, has the potential to affect the DOM of the river and DOM release from the sediment. Rainfall is a natural phenomenon that is responsible for increasing the transport of sediments and contaminants into rivers (Ramos et al., 2015). Previous studies have demonstrated that river DOM concentrations are associated with the rainfall-runoff processes during the rainy season (Inamdar et al., 2011; Ritson et al., 2014; Tao, 1998). In summer the level of allochthonous DOM is higher than that of autochthonous DOM owing to rainwater inflow; however, in winter, the contrary is observed $(T a o, 1998)$. Moreover, the nutrient dynamics of sediment in rivers are related to rainfallrunoff processes and the intensity and frequency of rainfall (Ramos et al., 2015).

The measurements of optical properties, such as absorption and fluorescence spectroscopy, have been widely utilized to investigate the composition, distribution and dynamics of DOM in aquatic systems over recent decades (Chen and Hur, 2015; Coble, 1996; Hudson et al., 2007; Inamdar et al., 2011; Mcknight et al., 2001). In particular, fluorescence spectroscopy has been used to characterize DOM with high sensitivity, simplicity, and reliability (Coble, 1996; Hur et al., 2006; Leenheer \& Croue, 2003). Specific ultraviolet absorbance $\left(\mathrm{SUVA}_{254}\right)$, which is used to monitor DOM optical properties, can be used to estimate the presence of aromatic organic carbon compounds in DOM according to rainfall. SUVA 254 is high when $\mathrm{HMW}$ organic matter originating from the humus in forests and soils is introduced into rivers through rainfall ( $\mathrm{Li}$ et al., 2005). An increase in river water level owing to rainfall can enhance the release rate of soluble organic carbon from the sediments as well as the DOC concentrations in the bottom water layer (Bin et al., 1997; Lefrançois et al., 2007; Ramos et al., 2015). Determining the release rate and the chemical composition of DOM is crucial for understanding both the fate of the sediment DOM and the ecological and biogeochemical effects of DOM in the bottom water.

In aquatic ecosystem, sediment serves as a source of DOM through the release to the bottom water. Considering the accumulation and the release of the sediment affected by rainfall, it would be highly valuable to explore the quantity and quality of DOM released from the sediment counting on the effect of the rainfall. Most previous studies have primarily applied the optical techniques to characterize DOM at the river water after rainfall. However, little study have been conducted to investigate DOM released from the sediment after rainfall. Therefore, this study investigated the DOM released from the sediment samples with spatial and seasonal variation using the incubation experiments. The objectives of our study are: (1) understand the contribution of DOM released from sediment to the quantity and quality of the overlying water via incubation, (2) analyze optical properties of DOM released from sediment using fluorescence analysis, and (3) identify the essential environmental factors that affect the DOC release rate and optical properties of DOM via statistical analyses. The result of this study will have implications for better restraining the DOM movement in aquatic ecosystem and for inferring the influences of environmental factors, especially rainfall, on the quantity and quality of DOM in the bottom water. 


\section{Materials And Methods \\ Site description}

This study was conducted within the Namhan River watershed, which is $375 \mathrm{~km}$ long, covers an area of 23,859 $\mathrm{km}^{2}$ along the primary river (Lee et al., 2012; Park et al., 2008), and is located in the eastern region of South Korea. The annual average temperature of the watershed was $13.0^{\circ} \mathrm{C}\left(-13.5-30.0^{\circ} \mathrm{C}\right)$ in 2016 and $12.3^{\circ} \mathrm{C}\left(-9.8-29.9^{\circ} \mathrm{C}\right)$ in 2017 . The East Asian summer monsoon climate influences the hydrologic characteristics of the watershed, with over $50 \%$ of the annual precipitation falling in July and August. The annual precipitation was $935.9 \mathrm{~mm}$ from 89 days of rain or snow at a rate of over $0.1 \mathrm{~mm} /$ day in 2016 and $1188.4 \mathrm{~mm}$ from 111 days in 2017 (Korea Meteorological Administration, http://weather.go.kr, 20162017).

\section{Sampling and sample preparation}

As a part of a large river restoration project designed to control flooding and water supply, multipurpose weirs have been constructed along the Namhan River (Fig. 1). Weir construction is known to exert impacts on the quantity and quality of sediment DOM by facilitating the accumulation of sediments near the weir (Chen et al., 2016). On four different days between August 2016 and June 2017, sediment samples were collected upstream of the Gangcheon $\left(37^{\circ} 16^{\prime} 29.50^{\prime \prime} \mathrm{N}, 127^{\circ} 41^{\prime} 13.70 " \mathrm{E}\right)$, Yeoju $\left(37^{\circ} 19^{\prime} 9.10^{\prime \prime} \mathrm{N}, 127^{\circ} 37^{\prime} 14.80^{\prime \prime} \mathrm{E}\right)$, and Ipo weir (37² $\left.24^{\prime} 8.30^{\prime \prime} \mathrm{N}, 127^{\circ} 32^{\prime} 29.00^{\prime \prime E}\right)$.

For incubation, acrylic core samplers with rubber stopper (diameter and height of 10 and $22 \mathrm{~cm}$, respectively) were used to collect a $15 \mathrm{~cm}$-height sediment core together with the overlying water by a scuba diver. Three sediment cores were sampled for the incubation $(n=1)$, for the analysis of the sediment $(n=1)$ and pore-water $(n=1)$ chemistry at each weir. The bottom water was separately collected in separate bottles using a Niskin water sampler. The core and bottom water samples were carefully placed vertical in ice box while they were transported to the laboratory (Lee et al., 2018).

Given that rainfall has an effect on sediment composition and characteristics, the sampling was divided into two periods: rainy and non-rainy seasons. Based on close observation of the rainfall pattern in the Namhan River watershed, the samples collected in August 2016 were classified as rainy season samples, whereas those collected in October 2016, May 2017, and June 2017, were classified as non-rainy season samples (Fig. 2). In particular, water flowing into rivers through the watershed owing to rainfall contains allochthonous origin pollution, especially OM (Inamdar et al., 2011). The DOM optical properties in river sediments depend on the land type and use in the watershed (Correll et al., 2001).

The sediment samples were retrieved from the upper part $(0-2 \mathrm{~cm})$ of the core and homogeneously mixed in a nitrogen purged vinyl bag (Cho et al., 2002; Fig. S1). The homogeneously mixed sediment (45 g) was placed in a $100 \mathrm{ml}$ serum vial containing $70 \mathrm{ml}$ of bottom water filtered using Whatman GF/F filters $(0.7 \mu \mathrm{m}$, Thurman, 1985$)$. The filtered bottom water was poured into the vial, being careful not to mix it with the sediment. Filtered river water was used for the incubation because the incubation 
experiment reproduce the real environmental condition of study area. The top of the vials was packed with glass wool to prevent evaporation of the water and vials was not shaken during incubation. The vials containing sediment and the bottom water were incubated to estimate the change in OM concentration released from the sediments into the water layer. The changes of OM concentration can help understanding the contribution DOM released from the sediments to the condition of water layer, such as anoxic and eutrophication.

Laboratory incubation was carried out in a dark chamber where the ambient temperature was kept constant at $20^{\circ} \mathrm{C}$ for up to 7 days (Kalbitz et al., 2003; Luek et al., 2017). The average residence time of the weirs constructed in 4 major rivers (Han, Geum, Nakdong, and Youngsan River) of South Korea was $2.46 \pm 2.78$ days for rainy season and $7.63 \pm 8.25$ days for non-rainy season in 2016-2017. Therefore, the sample vial was incubated for 3 and 7 days. A total of 9 vials were incubated at each site (Gangcheon, Yeoju, and Ipo). At 0, 3 and 7 days of incubation, 3 vials from each site were sacrificed for analysis. In addition, in August and October 2016, vials containing bottom water without sediments (control) were incubated under the same conditions to estimate the change in DOM influenced by the bottom water only.

\section{Analytical methods}

After incubation, the supernatant collected without disturbing the sediment in the vials was filtered (Kalbitz et al., 2003), and DOC concentrations were measured using a total organic carbon (TOC) analyzer (V-CPH, Shimadzu, Japan). After removing the particulate organic carbon using a GF/F filter, the DOC was measured using a non-purgeable organic carbon (NPOC) method. The DOC release rate $\left(\mathrm{mg} / \mathrm{m}^{2} /\right.$ day) was calculated as the difference in concentration of DOC between 0 and 3 Days $\left(\right.$ DOC $_{3 \text { day }}$ - $\mathrm{DOC}_{0 \text { day }}$ ), multiplied by the volume of the supernatant in the sample vial, and divided by the area of the surface sediment and the number of days of incubation (Cho and Chung, 2007).

The absorbance spectra from 100 to $900 \mathrm{~nm}$ were measured using a UV-visible spectrophotometer (Libra S32 PC, Biochrom, UK). Fluorescence intensity was determined using the fluorescence excitationemission matrix (EEM) technique (F-7000, Hitachi, Japan). The EEMs were scanned the excitation wavelengths of 200-400 nm with a stepwise increase of $5 \mathrm{~nm}$ and at emission wavelengths of 290-540 $\mathrm{nm}$ with $1 \mathrm{~nm}$ increments. Excitation and emission slits were both adjusted to $5 \mathrm{~nm}$.

The absorbance and fluorescence intensities of the samples were used to calculate SUVA 254 , the humification index (HIX), and the fluorescence index (FI). SUVA 254 , which is an indicator of the presence of aromatic organic carbon compounds in DOM, is calculated by dividing the absorbance at $254 \mathrm{~nm}$ by the DOC concentration (Kaplan et al., 1993). If it is higher than 4, it implies that the DOM predominantly consists of hydrophobic and HMW organic matter. If it is less than 2, it implies that hydrophilic and LMW organic matter are dominant (Ates et al., 2007).

The HIX was calculated using the $435-480 \mathrm{~nm}$ to $300-435 \mathrm{~nm}$ ratio of the spectral region areas of the emission spectra at an excitation wavelength of $254 \mathrm{~nm}$ (Zsolnay et al., 1999). The HIX, which is often considered an indicator of DOM maturity, represents the degree of humification (Lu et al., 2000). It 
increases as microorganism-induced humification increases (McKnight et al., 2001), i.e., if it is below 10, the DOM is not strongly humified, and contains more oxygen-containing functional groups (Zsolnay et al., 1999).

The $\mathrm{Fl}$, which is an indicator of $\mathrm{OM}$ origin, was calculated using the ratios of the emission intensity at 450 $\mathrm{nm}$ and $500 \mathrm{~nm}$ to the excitation at $370 \mathrm{~nm}$ (McKnight et al., 2001). Fl is an indicator of OM origin; when it is below 1.4, it implies the presence of significant levels of terrestrial and aromatic organic carbon; when it is above 1.9, it implies the presence of organic material with low amounts of aromatic organic carbon originating from microorganisms (McKnight et al., 2001).

PARAFAC analysis was performed on the 107 EEMs generated from the incubated samples collected from the Gangcheon, Yeoju, and Ipo weirs. Using two components, the model generated the best statistical results and was able to explain more than $99.9 \%$ of the EEMs. PARAFAC modeling was conducted using MATLAB 7.6 (MathWorks, Natick, MA, USA) with the N-way toolbox (Anderson \& Bro, 2000). A total of 107 EEMs from Gangcheon, Yeoju, and Ipo for the four sampling periods were identified and used to produce two representative PARAFAC components.

The in situ temperature and DO concentration for the surface and bottom water layers were measured using a multiparameter instrument (professional plus, YSI, USA). The physical and chemical characteristics of the sediments $(0-2 \mathrm{~cm})$, including particle size, pore-water nitrogen (total dissolved nitrogen (TDN) and dissolved organic nitrogen (DON)) and sediment TOC, were measured.

Particle size was determined by sieving the sediments and using an automatic particle size analyzer after removing carbonate and OM using hydrogen peroxide (Mastersizer 2000, Malvern, UK). Samples for the pore-water DON and TDN concentrations were collected using a Rhizon sampler (Rhizon CCS, Rhizosphere). The TDN in the pore-water samples was measured by a total organic carbon analyzer (TOC-VCPN, Shimadzu, Japan). The DON concentration was calculated by subtracting the dissolved inorganic nitrogen $\left(\mathrm{NH}_{3}-\mathrm{N}, \mathrm{NO}_{2}-\mathrm{N}\right.$, and $\left.\mathrm{NO}_{3}-\mathrm{N}\right)$ from the TDN. Concentrations of $\mathrm{NH}_{3}-\mathrm{N}$ were determined based on the phenate method (standard methods $4500-\mathrm{NH}_{3}$ ), and the concentrations of $\mathrm{NO}_{2}-\mathrm{N}$ and $\mathrm{NO}_{3}-\mathrm{N}$ were measured by ion chromatography (790 Personal IC, Metrohm, Switzerland). The sediment samples were freeze-dried and crushed in an agate mortar. An elemental analyzer (EA 1110, GV instruments, UK) was used to determine the TOC after removing inorganic carbonate using $1.0 \mathrm{~N}$ hydrochloric.

In the rainy season, a large amount of contaminants flows into rivers with surface runoff by rainfall (Jorgensen, 2003; Fonseca et al., 2016). In addition, the inflow of surface runoff increases the flow rate of a river, which affects the transport and accumulation of sediment (Zhao et al., 2018). Therefore, residence time and precipitation of weirs are considered environmental factors that affect the quantity and quality of sediment. The residence time was calculated by dividing the volume of the water body by the inflowing water volume based on data provided by the Korea Water Resources Corporation (K-water, http://water.or.kr). For precipitation, the previous 1 month average precipitation was provided by K-water which was used depending on the sampling location and date. 


\section{Statistical analyses}

To investigate significant differences between the sampling sites and periods with respect to the physical and chemical characteristics of the samples, such as particle size, surface and bottom water DO concentrations and temperature, pore-water TDN, DON, sediment TOC, residence time and precipitation, one-way analysis of variance (ANOVA) was conducted (IBM SPSS Statistics, IBM, USA). Linear regression analysis of the relationship between the DOM properties and environmental factors was performed (Sigmaplot 10.0, Systat Software, USA). Principal component analysis (PCA) was also conducted to illustrate the association of DOC and optical properties of DOM and environmental factors using Unscrembler X 10.1 (CAMO software, Norway; Anzano et al., 2011).

\section{Results And Discussion}

\section{Physical and chemical characteristics of the study area}

The sediment particle size, temperature, and DO concentration of the surface and bottom water layers were measured at the sampling sites, and the results are shown in Table 1. The average surface and bottom water temperatures were $24.4 \pm 2.17{ }^{\circ} \mathrm{C}$ and $25.1 \pm 2.85^{\circ} \mathrm{C}$ in the rainy season (August 2016) and $20.61 \pm 2.88{ }^{\circ} \mathrm{C}$ and $20.21 \pm 2.86^{\circ} \mathrm{C}$ in the non-rainy season (Table 1). The temperatures of the surface and bottom water layers were significantly higher in the rainy season (August 2016) than non-rainy season (May 2017; one-way ANOVA, $p<0.05$ ). Additionally, the differences between the surface and bottom water temperatures were below $2{ }^{\circ} \mathrm{C}$ across all sampling sites and sampling periods, and no stratification was observed. The DO concentrations of the surface and bottom water layers were $8.91 \pm 1.20 \mathrm{mg} / \mathrm{L}$ and $8.52 \pm 1.56 \mathrm{mg} / \mathrm{L}$, respectively. Since the degree of DO saturation of the bottom water layer was in the range of $71-135 \%$, no oxygen depletion was observed. The sediment particle size ranged from $0.013 \mathrm{~mm}$ to $0.363 \mathrm{~mm}$ at the Gangcheon weir, from $0.029 \mathrm{~mm}$ to $0.068 \mathrm{~mm}$ at the Yeoju weir, and from $0.056 \mathrm{~mm}$ to $0.23 \mathrm{~mm}$ at the Ipo weir. There were no significant differences between the sampling sites and sampling periods with respect to particle size and DO concentrations (one way ANOVA, $p>0.05$ ). Porewater TDN and DON concentration were in the range 1.76-8.79 mg/L and 0.61-5.12 mg/L, respectively. There was no significant differences in sampling periods and sites (one way ANOVA, $p>0.05$ ). The previous study conducted on sediments of 4 major rivers showed that the concentration of TDN was $12.08 \pm 8.90 \mathrm{mg} / \mathrm{L}$ in July-August and $9.63 \pm 6.36 \mathrm{mg} / \mathrm{L}$ in September-October of 2016 (Lee et al., 2018). DON concentration was $12.00 \pm 8.93 \mathrm{mg} / \mathrm{L}$ in July-August and $9.34 \pm 6.42 \mathrm{mg} / \mathrm{L}$ in September-October at the same study. From the comparison of the concentrations TDN $(4.46 \mathrm{mg} / \mathrm{L}$ in August and $4.03 \pm 2.13$ $\mathrm{mg} / \mathrm{L}$ in October) and DON (4.32 mg/L in August and $3.26 \pm 2.36 \mathrm{mg} / \mathrm{L}$ in October) of this study, it can be concluded that Han River has lower concentrations of pore-water TDN and DON than other rivers in Korea (including Geum, Yeongsan, and Nakdong Rivers).

TOC concentration of surface sediment was in the range $0.36-3.59 \%$, and it also had no statistical difference in temporal and spatial. The residence time was $0.58 \pm 0.30 \mathrm{~d}$ in the rainy season, and $1.91 \pm 0.40 \mathrm{~d}$ in the non-rainy season. Precipitation was $7.19 \pm 3.21 \mathrm{~mm} / \mathrm{d}$ in the rainy season, and 
$1.52 \pm 1.01 \mathrm{~mm} / \mathrm{d}$ in the non-rainy season. There was a significant difference in the residence time and precipitation between the sampling periods, the rainy and non-rainy season (one-way ANOVA, $p<0.05$ ).

Table 1

Physical and chemical characteristics of the study area

\begin{tabular}{|c|c|c|c|c|c|c|}
\hline Weir & Date & $\begin{array}{l}\text { Particle } \\
\text { size } \\
(\mathrm{mm})\end{array}$ & $\begin{array}{l}\text { Surface } \\
\text { temp. } \\
\left({ }^{\circ} \mathrm{C}\right)\end{array}$ & $\begin{array}{l}\text { Bottom } \\
\text { temp. } \\
\left({ }^{\circ} \mathrm{C}\right)\end{array}$ & $\begin{array}{l}\text { Surface } \\
\text { DO } \\
\text { (mg/L) }\end{array}$ & $\begin{array}{l}\text { Bottom } \\
\text { DO } \\
(\mathrm{mg} / \mathrm{L})\end{array}$ \\
\hline \multirow[t]{4}{*}{ Gangcheon } & Aug. 2016 & - & 21.9 & 22.0 & 7.6 & 8.6 \\
\hline & Oct. 2016 & 0.030 & 21.2 & 21.1 & 8.0 & 7.8 \\
\hline & May 2017 & 0.013 & 15.9 & 15.5 & 10.1 & 9.9 \\
\hline & Jun. 2017 & 0.363 & 23.5 & 21.6 & 9.8 & 6.3 \\
\hline \multirow[t]{4}{*}{ Yeoju } & Aug. 2016 & - & 25.7 & 27.6 & 8.9 & 9.5 \\
\hline & Oct. 2016 & 0.030 & 21.6 & 21.2 & 8.3 & 6.8 \\
\hline & May 2017 & 0.029 & 19.3 & 18.5 & 9.8 & 10.2 \\
\hline & Jun. 2017 & 0.068 & 24.4 & 24.4 & 7.7 & 7.4 \\
\hline \multirow[t]{4}{*}{ Ipo } & Aug. 2016 & - & 25.6 & 25.7 & 7.5 & 7.6 \\
\hline & Oct. 2016 & 0.230 & 18.2 & 18.1 & 8.5 & 7.5 \\
\hline & May 2017 & 0.068 & 18.2 & 18.1 & 9.4 & 9.2 \\
\hline & Jun 2017 & 0.056 & 23.2 & 23.4 & 11.4 & 11.5 \\
\hline \multicolumn{7}{|c|}{ Temp.: temperature; DO: dissolved oxygen } \\
\hline
\end{tabular}

The initial DOC concentration (Day 0) in the bottom water from the Gangcheon, Yeoju, and Ipo weirs was 1.27-3.48 mg/L (Fig. 3a). There were significant differences in the initial concentration of DOC in the rainy season (average $2.21 \pm 0.04 \mathrm{mg} / \mathrm{L}$ ) and non-rainy season (average $2.03 \pm 0.60 \mathrm{mg} / \mathrm{L}$; one-way ANOVA, $p<0.05)$. The DOC concentration in the water layer tended to increase according to the incubation time, and the rate of increase within the first three days of incubation was higher than that observed within days $3-7$. DOC release rate between 0 and 3 day of incubation were in the ranges $0.015-0.062$ $\mathrm{mg} / \mathrm{m}^{2} /$ day. There was no significant differences in DOC release rate in rainy season $(0.025-0.062$ $\mathrm{mg} / \mathrm{m}^{2} /$ day) and non-rainy season (0.015-0.043 mg/m²/day; one-way ANOVA, $\left.\mathrm{p}>0.05\right)$. However, DOC release rate in the Gangcheon $\left(0.031-0.043 \mathrm{mg} / \mathrm{m}^{2} /\right.$ day) and Yeoju weirs $\left(0.033-0.062 \mathrm{mg} / \mathrm{m}^{2} /\right.$ day $)$ were significantly higher than Ipo weir $\left(0.015-0.027 \mathrm{mg} / \mathrm{m}^{2} /\right.$ day; one-way ANOVA, $\left.\mathrm{p}<0.05\right)$. 
To examine the effect of sediment on DOC concentration, the bottom water without the sediments (control) was incubated under the same conditions as the sample vials containing the sediments (Fig. 3a). The DOC concentration increased from -4 to $22 \%$ (average, $11 \%$ ) in the control and from 78 to $104 \%$ (average, $89 \%$ ) in the sample with the sediment. The results of the control indicated that the increase observed in the sample vials containing the sediments primarily resulted from the DOC released from the sediments. During the incubation, the apparent DOC increase in the sample vials containing the sediment may result not only from physical transport such as diffusion but also from various biogeochemical processes such as microbial degradation at the sediment-water interface. From the result of incubation, it could be concluded that DOC released from sediment plays an essential role in increasing bottom water DOC concentration.

Since the initial DOC concentration was different depending on the sampling period, the relationship between DOC concentration and sampling period was examined. The main characteristics, amount of precipitation and residence time, were selected to represent the sampling period of rainy and non-rainy season. The initial DOC concentration was positively correlated with the amount of precipitation ( $p=$ 0.0042 ; Fig. 3b) and negatively correlated with residence time $(p=0.0473$; Fig. $3 c)$. Heavy rainfall results in an increase in river inflow, which leads to a decrease in residence time. Additionally, water flowing from a watershed contains allochthonous pollutants, particularly $\mathrm{OM}$, which has characteristics that depend on the land type and use of the watershed (Tao, 1998; Correll et al., 2001). However, unlike the initial DOC concentration, there was no statistically significant correlation between the DOC release rate and either precipitation or residence time ( $p=0.286$ and 0.322 , respectively). Based on the relationship among the initial DOC concentration, the amount of precipitation and residence time, it can be concluded that environmental factors, such as precipitation and residence time, have an effect on the DOC concentration of the bottom water (Inamdar et al., 2011). However, there was no significant relationship among the DOC release rate, precipitation and residence time.

\section{Optical properties of DOM}

The initial SUVA 254 values at the Gangcheon, Yeoju, and Ipo weirs in non-rainy season were in the range of $0.68-2.26$ (Fig. 4a), these values were below 4, indicating the predominance of hydrophilic and LMW organic matter. However, it were ranged 3.42-9.19 in rainy season, especially in Gangcheon and Ipo weir were above 4, indicating the predominantly consists of hydrophobic and HMW organic matter. There were significant differences between rainy and non-rainy season with respect to initial SUVA 254 (one-way ANOVA, $p$ <0.05). The SUVA 254 increased during incubation period, except August 2016 in Yeoju weir and August and October in Ipo weir. The change of $\mathrm{SUVA}_{254}$ during the sediment incubation period means that the properties of DOM can be affected by the DOM released from the sediment into the water layer. The SUVA $_{254}$ release rate was significantly difference between during the rainy season (August 2016) and during non-rainy season $(p<0.05)$. This could be attributed to the introduction of HMW organic matter into rivers from watersheds during the rainy season ( $\mathrm{Li}$ et al., 2005). According to previous studies, SUVA $_{254}$ value has significant correlation with DBP produced in drinking water treatment processes (Amy et al., 1986; Jung and Son, 2008). Water layer containing hydrophobic and HMW organic matters in the 
rainy season, where SUVA 254 are relatively high, can cause DBP in water treatment plants at Namhan River. Therefore, special caution needs to operation of the drinking water processes during the rainy season rather than non-rainy season.

The HIX values of the samples collected at the Gangcheon weir were in the range of 2.72-4.85, whereas those of the samples collected at the Yeoju and Ipo weirs were in the ranges of 3.08-4.15 and 2.76-4.25, respectively (Fig. 4b). The HIX values tended to decrease with incubation time, and a considerable decrease was observed within the first three days. Since decreases in HIX can result from decrease in microorganism-induced humification, and HIX below 10 means that the DOM is not strongly humified and contains more oxygen-containing functional groups (Zsolnay et al., 1999; McKnight et al., 2001). Based on these observations, it could be concluded that microorganism-induced humification did not occur during the incubation period and that there was an increase in the concentration of functional groups, particularly oxygen-containing functional groups according to DOC release. (Supplementary materials Text S1) present HIX changes of water extractable organic matter (WEOM) during the incubation. Supplementary materials provide that the organic matter released from the sediment to the water layer is not humified by microorganism in the water layer during incubation period (Fig. S2 and3.)) There were no significant differences between the sampling sites and sampling periods with respect to initial HIX and HIX flux.

The FI values of the samples collected at the Gangcheon, Yeoju, and Ipo weirs were in the ranges of 1.43-1.82, 1.42-1.83, and 1.46-1.83, respectively (Fig. 4c). When FI values are below 1.4, it implies the presence of significant levels of terrestrial and aromatic organic carbon; when they are above 1.9, it implies the presence of organic material with low amounts of aromatic organic carbon originating from microorganisms (McKnight et al., 2001). Given that the Fl values at the three weirs fell within the 1.4 to 1.9 range, it implied that the samples contained $\mathrm{OM}$ originating from both terrestrial and microbial sources (McKnight et al., 2001). Additionally, the FI values recorded in 2017 were significantly higher than those recorded in 2016 ( $p$ 0.0001) because, in 2016, sampling was performed during the rainy season (August 2016). Hence, more terrestrial OM was present relative to the samples collected in 2017. This is consistent with a previous study, which revealed that during the rainy season (August 2016), more DOM originating from terrestrial sources is present relative to other periods (Sieczko \& Peduzzi, 2014). As an indicator of OM origin, there were slight changes in the FI values during the incubation period $(p>0.05$; except October 2016).

The results of our PARAFAC analysis using 107 EEMS are shown in Fig. 5a and b. The fluorescence components of the incubated samples were estimated from the excitation and emission characteristics of components reported in previous studies. The two fluorescence components are represented as $\mathrm{C} 1$ and C2. C1 exhibited maximum peaks at excitations of $<250 \mathrm{~nm}$ and $330 \mathrm{~nm}$ and emission at $440 \mathrm{~nm}$ (Fig. 5a). Coble (1996) and Stedmon and Markager (2005) reported peaks similar to the $\mathrm{C} 1$ peaks observed in this study. According to Coble (1996), C1 represents humic-like compounds of terrestrial origin found in many natural aquatic systems. C2 showed maximum peaks at excitations of $<250 \mathrm{~nm}$ and $280 \mathrm{~nm}$ and emission at $370 \mathrm{~nm}$ (Fig. 5b), which are similar to the peaks reported by Stedmon and 
Markager (2005) and Sanchez et al. (2013). According to these previous studies, C2 resembles proteinlike compounds, specifically tryptophan-like substances, originating from autochthonous processes. These tryptophan-like substances are produced by phytoplankton and algae; thus, they likely affect primary productivity in the water layer, resulting in the production of chlorophyll-a.

The change in $\mathrm{C} 1$ intensity according to incubation is shown in Fig. $5 \mathrm{c}$. The intensity of $\mathrm{C} 1$, a terrestrial humic-like substance, generally increased with incubation time. The intensity of the components obtained from PARAFAC indicated the relative concentrations of the corresponding components (Kim et al., 2016). Thus, the increase in $\mathrm{C} 1$ indicates that the allochthonous origin humic-like substance is contained in the DOC released from the sediment into the water layer. The increase in $\mathrm{C} 1$ within the first three days of incubation was greater than that observed within the remaining incubation time. However, the difference in the $\mathrm{C} 1$ change between the rainy and non-rainy season was not clear.

Similar to the change in $\mathrm{C} 1$ intensity, there was an increase in the intensity of $\mathrm{C} 2$, a tryptophan-like substance produced by phytoplankton and algae inside the water body (Fig. $5 \mathrm{~d}$ ). This means that the DOM containing tryptophan-like substance was released from the sediment into the water layer. The increase in C2 intensity was statistically greater in the non-rainy season than in the rainy season $(p<0.05)$, when there was no previous precipitation. This result is similar to the FI results for non-rainy season, where there was more autochthonous origin DOM than allochthonous origin DOM. Therefore, in the nonrainy season without previous rainfall, tryptophan-like substances generated from phytoplankton and algae can affect the DOM concentration of the water layer.

The analysis of the DOM optical properties revealed that the DOM released from sediments to the water layer primarily contained non-humified hydrophilic and LMW organic matter in non-rainy season. However, during the rainy season in August 2016, hydrophobic and HMW organic matter was released from sediment. With respect to the origin of the OM, the DOM in the water layer originated from both autochthonous and allochthonous sources. During the rainy season (August 2016), more OM originating from allochthonous sources was observed, and during May-June 2017 of non-rainy season, more OM originating from autochthonous sources, such as tryptophan-like compounds, was observed.

\section{Relationship between DOM and environmental factors}

Most of the changes in the measured variables were observed within the first three days of incubation; thus, statistical analyses were performed only on data collected during this period. Physical characteristics (surface and bottom temperatures, residence time, precipitation, and sediment particle size) and chemical characteristics (surface and bottom water layer DO, surface sediment TOC concentration, and pore-water TDN and DON contents) were considered environmental factors in this analysis, and all variables were standardized on the same scale.

Linear regression analyses between the properties of DOM (released DOC, SUVA $254, \mathrm{Fl}, \mathrm{HIX}, \mathrm{C1}$, and C2) and environmental factors were performed, and the results are shown in Fig. 6 . The wind-rose diagrams of the correlation between the six DOM properties could be divided into two categories based on their 
association with environmental factors. The value of the wind-rose diagram indicates Pearson's R. If Pearson's R is positive, the properties of DOM and environmental factors have a positive relationship, and if it is negative, it has a negative relationship. The DOC release rate was positively correlated with porewater TDN, DON and sediment TOC concentrations ( $p=0.002,0.029$, and 0.035 , respectively). When the pore-water nitrogen concentration and surface sediment organic carbon concentration were high, the concentration of DOC released from the sediment was also high. This suggests that the dissolved nitrogen concentration in pore-water is the factor controlling the DOC release rate (Panton et al., 2020). This result also suggests that sediment carbon was a source of DOC for the water layer (Chen and Hur, 2015; Brasilsford et al., 2019). Additionally, the HIX release rate, which is an indicator of the degree of humification, was positively correlated with the surface and bottom layer DO concentrations $(p=0.037$ and 0.021 , respectively). This means that the HIX values tended to be higher when more oxygen was associated with the $\mathrm{OM}$. This is consistent with previous studies showing that there is a correlation between HIX and oxygen concentration (Calleja et al., 2019). From the linear regression results, we confirmed that the DOC release rate, dissolved nitrogen of the pore-water, and TOC of the sediment were related and that HIX was related to the oxygen concentration in the water layer. According to the regression analysis results, sediment released DOM and its optical properties are influenced by the environmental factors of the bottom water and sediments.

The PCA was performed using data on the DOM optical properties and environmental factors from the Gangcheon, Yeoju, and Ipo weirs collected between August 2016 and June 2017 (four sampling periods). The first two PCs explained more than 50\% of the data (PC1: $30 \%$ and PC2: $21 \%$ ), and each point in the scatter plot represents one spectrum. Fig. $6 f$ shows that PC1 and PC2 could lead to apparent clustering. The data obtained during the rainy season (August 2016) were located on the positive side of PC1, whereas those obtained during the non-rainy season (October 2016, May and June 2017) tended to be distributed on the negative side of PC1. In addition, precipitation had a strong positive value for PC1 in the loading value, but the residence time had a strong negative value. This means that precipitation and residence time related to the flow rate of the river are highly related to PC1. This result is similar to the ANOVA result in which the initial DOC concentration had a significant correlation with precipitation and residence time. However, there was no obvious difference between the sampling locations (Fig. $6 \mathrm{~g}$ ). Thus, the PCA results show that the optical properties of DOM and environmental factors changed with season rather than sampling location.

\section{Summary And Implications}

In this study, we investigated the spatial and seasonal variations in sediment released DOM and their optical properties to estimate the contribution of the sediment to the quantity and quality of DOM in the overlying water. Sediment and bottom water samples were collected upstream of three weirs in the Namhan River during the rainy and non-rainy seasons.

Vials containing the sediment and bottom water samples were incubated for up to seven days at $20^{\circ} \mathrm{C}$. The supernatant in the vials was analyzed to determine the DOC concentrations and optical properties of 
the DOM during incubation. The physical and chemical characteristics of the sediments, such as particle size and TOC, were measured. According to the incubation experiment, the change in bottom water DOC concentration resulted from the DOC released from the sediments. The initial DOC concentration was different in the rainy season $(2.21 \pm 0.04 \mathrm{mg} / \mathrm{L})$ and in non-rainy season $(2.03 \pm 0.60 \mathrm{mg} / \mathrm{L})$. In addition, the initial DOC concentration was positively correlated with the amount of precipitation $(p=0.0042)$ and negatively correlated with residence time $(p=0.0473)$. However, there was no significant relationship among the $\mathrm{DOC}$ release rate in terms of the sediments, amount of precipitation or residence time.

Fluorescence analysis together with SUVA $254, \mathrm{HIX}, \mathrm{FI}$, and PARAFAC measurements were used to determine the optical properties of the DOM during incubation. The SUVA 254 results showed that DOM from sediment contained higher levels of hydrophilic and LMW organic matter in non-rainy season, and hydrophobic and HMW organic matter in rainy-season. HIX and FI results showed that the organic matter in the water layer originated from both terrestrial and microbial sources; however, during the rainy season, more organic matter originating from terrestrial sources was present. The results of PARAFAC analysis consistently revealed that tryptophan-like compounds, originating from phytoplankton or algae was statistically greater in the water layer during the non-rainy season. The DOM with high value of $\mathrm{SUVA}_{254}$ may cause challenges for water quality, safety and treatment issues. The DOM fraction with high value of SUVA $_{254}$ which means hydrophobic and HMW organic matters are reported to have closely associated with DBP formation potentials (Amy et al., 1986; Croue et al., 2000; Jung and Son, 2008). Since the Namhan River is the main resource of drinking water for Seoul metropolitan area, special caution needs to be taken for water treatment during the rainy season when the DOM have a large amount of hydrophobic and HMW organic fractions. Our results can help design and optimizes drinking water treatment processes, such as granular activated carbon and membrane filtration, to minimize the risks of DBP production by timely reflecting the DOM characteristics varying with season and precipitation patterns (Yu et al., 2003).

The linear regression analysis between the properties of the DOM (released DOC, SUVA $254, \mathrm{FI}, \mathrm{HIX}$, C1, and C2) and environmental factors revealed that pore-water nitrogen (TDN, $p=0.002 ; D O N, p=0.029$ ) and sediment TOC $(p=0.035)$ correlated with the DOC release from the sediment. Compared to previous studies conducted in other rivers (Kiber et al., 2006; Panton et al., 2020), our results suggest that the nutrient content of pore-water and sediment can be used to estimate the DOM release rate from sediment to water layer. This finding provided a better understanding of the relationship between the DOM released from sediment and environmental factors. However, more research is needed to clarify the spatial and seasonal variability of DOM movement in aquatic ecosystem and to understand their contribution on the quantity and quality of DOM in the surface waterbody.

\section{Declarations}

Funding: This research was supported by the Basic Science Research Program through the National Research Foundation of Korea (NRF) funded by the Ministry of Education (2018R1A6A1A08025520 and 
2016R1D1A1B04934910). Additional support was provided by Korea Ministry of Environment (Research on the effects of water quality due to environment of weir sediment) and the National Institute of Environmental Research in Korea.

Author Contributions: All authors certify that they have participated sufficiently in the work to take public responsibility for the content, including participation in the concept, design, analysis, writing, or revision of the manuscript.

Jung Hyun Choi: conceptualization, methodology, writing-review and editing, supervision, funding acquisition,

Haeseong Oh: validation, formal analysis, investigation, writing-original draft, Project administration, writing-review and editing, visualization

Data availability: The dataset used and/or analyzed during the current study are available from the corresponding author on reasonable request.

Ethics approval and consent to participate: Not applicable.

Consent for publication: Not applicable.

Competing Interests: The authors declare no competing interests.

\section{References}

1. Amy GL, Debroux J, Sinha S, Brandhuber P, Cho J (1986) Occurrence of disinfection by-products precursors in source water and DBPs in finished waters. In Proceedings of the Fourth International Workshop on Drinking Water Quality Management and Treatment Technology: 59-70

2. Andersen $\mathrm{CM}$, Bro R (2003) Practical aspects of PARAFAC modeling of fluorescence excitationemission data. J Chemometr 17(4):200-215. https://doi.org/10.1002/cem.790

3. Anzano J, Bonilla B, Montull-Ibor B, Casas-González J (2011) Plastic identification and comparison by multivariate techniques with laser-induced breakdown spectroscopy. J APPL POLYM SCI 121:2710-2716. https://doi.org/10.1002/app.33801

4. Ask J, Karlsson J, Persson L, Ask P, Byström P, Jansson M (2009) Terrestrial organic matter and light penetration: Effects on bacterial and primary production in lakes. LIMNOL OCEANOGR 54(6):20342040. https://doi.org/10.4319/lo.2009.54.6.2034

5. Ates $\mathrm{N}$, Kitis M, Yetis U (2007) Formation of chlorination by-products in waters with low SUVAcorrelations with SUVA and differential UV spectroscopy. Water Res 41(18):4139-4148. https://doi.org/10.1016/j.watres.2007.05.042

6. Bin L, Shu T, Xiaohang L (1997) RELEASE KINETICS OF WATER SOLUBLE ORGANIC COMPOUNDS FROM SOIL AND SEDIMENTS. ACTA SCIENTIAE CIRCUMSTANTIAE 1 (In Chinese) 
7. Brailsford FL, Glanville HC, Golyshin PN, Johnes PJ, Yates CA, Jones DL (2019) Microbial uptake kinetics of dissolved organic carbon (DOC) compound groups from river water and sediments. Sci Rep 9(1):1-11. https://doi.org/10.1038/s41598-019-47749-6

8. Calleja ML, Al-Otaibi N, Morán XAG (2019) Dissolved organic carbon contribution to oxygen respiration in the central Red Sea. Sci Rep 9(1):1-12. https://doi.org/10.1038/s41598-019-40753-w

9. Chen M, Hur J (2015) Pre-treatments, characteristics, and biogeochemical dynamics of dissolved organic matter in sediments: A review. Water Res 79:10-25. https://doi.org/10.1016/j.watres.2015.04.018

10. Chen M, He W, Choi I, Hur J (2016) Tracking the monthly changes of dissolved organic matter composition in a newly constructed reservoir and its tributaries during the initial impounding period. Environ Sci Pollut Res 23(2):1274-1283. https://doi.org/ 10.1007/s11356-015-5350-5

11. Cho KJ, Jung HY, Shin JK (2002) Assessment of environment, nutrient dissolution and internal load contribution of low-grade sediments in the lower part of the Nakdong River. Nakdong River 62:2-13 (In Korean)

12. Cho YC, Chung SW (2007) Sediment release rate of nutrients from Namyang reservoir. J Korean Soc Environ Eng 29(12):1345-1352 (In Korean)

13. Coble PG (1996) Characterization of marine and terrestrial DOM in seawater using excitationemission matrix spectroscopy. MAR CHEM 51(4):325-346. https://doi.org/10.1016/03044203(95)00062-3

14. Correll DL, Jordan TE, Weller DE (2001) Effects of precipitation, air temperature, and land use on organic carbon discharges from Rhode River watersheds. Water Air Soil Pollut 128(1-2):139-159. https://doi.org/10.1023/A:1010337623092

15. Croué JP, Violleau D, Labouyrie L (2000) Disinfection by-product formation potentials of hydrophobic and hydrophilic natural organic matter fractions: a comparison between a low-and a high-humic water. American Chemical Society, Washington, DC. http://doi.org/ 10.1021/bk-2000-0761.ch010

16. D'Andrilli J, Junker JR, Smith HJ, Scholl EA, Foreman CM (2019) DOM composition alters ecosystem function during microbial processing of isolated sources. Biogeochemistry 142(2):281-298. https://doi.org/10.1007/s10533-018-00534-5

17. Devesa-Rey R, Barral MT (2012) Allochthonous versus autochthonous naturally occurring organic matter in the Anllóns river bed sediments (Spain). Environ Earth Sci 66(3):773-782. https://doi.org/10.1007/s12665-011-1286-3

18. Fonseca ALDS, Bianchini I Jr, Pimenta CM, Soares CB, Mangiavacchi N (2016) The effect of hydrostatic pressure on the decomposition of inundated terrestrial plant detritus of different quality in simulated reservoir formation. Lake Reserv Manag 21(3):216-223. https://doi.org/10.1111//re.12139

19. Fovet O, Cooper DM, Jones DL, Jones TG, Evans CD (2020) Dynamics of dissolved organic matter in headwaters: comparison of headwater streams with contrasting DOM and nutrient composition. Aquat Sci 82(2):1-12. https://doi.org/10.1007/s00027-020-0704-6 
20. Hakanson L, Jansson M (1983) Principles of lake sedimentology. Springer-Verlag, Berlin

21. Hudson N, Baker A, Reynolds D (2007) Fluorescence analysis of dissolved organic matter in natural, waste and polluted waters-a review. River Res Appl 23(6):631-649. https://doi.org/10.1002/rra.1005

22. Hur J, Shin JK, Park SW (2006) Characterizing Fluorescence Properties of Dissolved Organic Matter for Water Quality Management of Rivers and Lakes. J Korean Soc Environ Eng 28(9):940-948 (In Korean)

23. Inamdar S, Singh S, Dutta S, Levia D, Mitchell M, Scott D, McHale P (2011) Fluorescence characteristics and sources of dissolved organic matter for stream water during storm events in a forested mid-Atlantic watershed. J Geophys Res Biogeosci 116(G3). https://doi.org/10.1029/2011JG001735

24. JØRGENSEN SE (2003) The application of models to find the relevance of residence time in lake and reservoir management. J Limnol 62(1s):16-20. https://doi.org/10.4081/jlimnol.2003.s1.16

25. Jung CW, Son HJ (2008) The relationship between disinfection by-products formation and characteristics of natural organic matter in raw water. Korean J Chem Eng 25(4):714-720. https://doi.org/10.1007/s11814-008-0117-z

26. Kalbitz K, Schmerwitz J, Schwesig D, Matzner E (2003) Biodegradation of soil-derived dissolved organic matter as related to its properties. Geoderma 113(3-4):273-291. https://doi.org/10.1016/S0016-7061(02)00365-8

27. Kaplan LA, Newbold JD (1993) Biogeochemistry of dissolved organic carbon entering streams. In: Ford TE (ed) Aquatic microbiology: An ecological approach. Blackwell Scientific Publications, Malden, Mass, pp 139-165

28. Kieber RJ, Whitehead RF, Skrabal SA (2006) Photochemical production of dissolved organic carbon from resuspended sediments. Kimnol Oceanogr 51(5):2187-2195. https://doi.org/10.4319/lo.2006.51.5.2187

29. Kim EA, Nguyen HVM, Oh HS, Hur J, Choi JH (2016) Influence of soil conditions on dissolved organic matter leached from forest and wetland soils: a controlled growth chamber study. Environ Sci Pollut Res 23(6):5203-5213. https://doi.org/10.1007/s11356-015-5740-8

30. Lee JE, Choi JW, An GG (2012) Influence of Landuse Pattern and Seasonal Precipitation on the Longterm Physico-chemical Water Quality in Namhan River Watershed. J Environ Sci 21(9):1115-1129. https://doi.org/10.5322/JES.2012.21.9.1115

31. Lee KY, Lee KC, Kim JE, Kim S, Ahn JM, Im TH (2015) A study on the nutrient release characteristics from sediments in nak-dong river. J Korean Soc Water Environ 31(6):644-652. https://doi.org/10.15681/KSWE.2015.31.6.644(In Korean)

32. Lee MH, Jung HJ, Kim SH, An SU, Choi JH, Lee HJ, Hur J (2018) Potential linkage between sediment oxygen demand and pore water chemistry in weir-impounded rivers. Sci Total Environ 619:16081617. https://doi.org/10.1016/j.scitotenv.2017.10.141 
33. Leenheer JA, Croué JP (2003) Peer reviewed: characterizing aquatic dissolved organic matter. Environ Sci Technol. https://doi.org/10.1021/es032333c. 18A-26A

34. Lefrançois J, Grimaldi C, Gascuel-Odoux C, Gilliet N (2007) Suspended sediment and discharge relationships to identify bank degradation as a main sediment source on small agricultural catchments. Hydrol Process 21(21):2923-2933. https://doi.org/10.1002/hyp.6509

35. Li F, Yuasa A, Muraki Y, Matsui Y (2005) Impacts of a heavy storm of rain upon dissolved and particulate organic $\mathrm{C}, \mathrm{N}$, and $\mathrm{P}$ in the main river of a vegetation-rich basin area in Japan. Sci Total Environ 345(1-3):99-113. https://doi.org/10.1016/j.scitotenv.2004.11.004

36. Lu XQ, Hanna JV, Johnson WD (2000) Source indicators of humic substances: an elemental composition, solid state 13C CP/MAS NMR and Py-GC/MS study. Appl Geochem 15(7):1019-1033. https://doi.org/10.1016/S0883-2927(99)00103-1

37. Luek JL, Thompson KE, Larsen RK, Heyes A, Gonsior M (2017) Sulfate Reduction in Sediments Produces High Levels of Chromophoric Dissolved Organic Matter. Sci Rep 7(1):8829. https://doi.org/10.1038/s41598-017-09223-z

38. McKnight DM, Boyer EW, Westerhoff PK, Doran PT, Kulbe T, Andersen DT (2001) Spectrofluorometric characterization of dissolved organic matter for indication of precursor organic material and aromaticity. Limnol Oceanogr 46(1):38-48. https://doi.org/10.4319/lo.2001.46.1.0038

39. Meyer JL, Edwards RT, Risley R (1987) Bacterial growth on dissolved organic carbon from a blackwater river. Microb Ecol 13(1):13-29. https://doi.org/10.1007/BF02014960

40. Mineau MM, Wollheim WM, Buffam I, Findlay SE, Hall RO Jr, Hotchkiss ER, Parr TB (2016) Dissolved organic carbon uptake in streams: A review and assessment of reach-scale measurements. J Geophys Res-Biogeosci 121(8):2019-2029. https://doi.org/10.1002/2015JG003204

41. Murphy KR, Stedmon CA, Graeber D, Bro R (2013) Fluorescence spectroscopy and multi-way techniques. PARAFAC Anal Methods 5(23):6557-6566. http://doi.org/10.1039/C3AY41160

42. Panton A, Couceiro F, Fones GR, Purdie DA (2020) The impact of rainfall events, catchment characteristics and estuarine processes on the export of dissolved organic matter from two lowland rivers and their shared estuary. Sci Total Environ 735:139481.

https://doi.org/10.1016/j.scitotenv.2020.139481

43. Park HK, Byeon MS, Choi MJ, Kim YJ (2008) The Effect Factors on the Growth of Phytoplankton and the Sources of Organic Matters in Downstream of Namhan-river. J Korean Soc Water Environ 24(5):556-562 (In Korean)

44. Ramos TB, Gonçalves MC, Branco MA, Brito D, Rodrigues S, Sánchez-Pérez JM, Pires FP (2015) Sediment and nutrient dynamics during storm events in the Enxoé temporary river, southern Portugal. CATENA 127:177-190. https://doi.org/10.1016/j.catena.2015.01.001

45. Ritson JP, Graham NJD, Templeton MR, Clark JM, Gough R, Freeman C (2014) The impact of climate change on the treatability of dissolved organic matter (DOM) in upland water supplies: a UK perspective. Sci Total Environ 473:714-730. https://doi.org/10.1016/j.scitotenv.2013.12.095 
46. Sanchez NP, Skeriotis AT, Miller CM (2013) Assessment of dissolved organic matter fluorescence PARAFAC components before and after coagulation-filtration in a full scale water treatment plant. Water Res 47(4):1679-1690. https://doi.org/10.1016/j.watres.2012.12.032

47. Shin Y, Lee EJ, Jeon YJ, Hur J, Oh NH (2016) Hydrological changes of DOM composition and biodegradability of rivers in temperate monsoon climates. J Hydrol 540:538-548. https://doi.org/10.1016/j.jhydrol.2016.06.004

48. Sieczko A, Peduzzi P (2014) Origin, enzymatic response and fate of dissolved organic matter during flood and non-flood conditions in a river-floodplain system of the Danube (Austria). Aquat Sci 76(1):115-129. https://doi.org/10.1007/s00027-013-0318-3

49. Stedmon CA, Markager S (2005) Resolving the variability in dissolved organic matter fluorescence in a temperate estuary and its catchment using PARAFAC analysis. Limnol Oceanogr 50(2):686-697. https://doi.org/10.4319/lo.2005.50.2.0686

50. Tao S (1998) Spatial and temporal variation in DOC in the Yichun River, China. Water Res 32(7):2205-2210. https://doi.org/10.1016/S0043-1354(97)00443-0

51. Thurman EM (1985) Organic Geochemistry of Natural Waters. Developments in Biogeochemistry. Springer, New York

52. Toming K, Tuvikene L, Vilbaste S, Agasild H, Viik M, Kisand A, Nõges T (2013) Contributions of autochthonous and allochthonous sources to dissolved organic matter in a large, shallow, eutrophic lake with a highly calcareous catchment. Limnol Oceanogr 58(4):1259-1270. https://doi.org/10.4319/lo.2013.58.4.1259

53. Tranvik LJ (1992) Allochthonous dissolved organic matter as an energy source for pelagic bacteria and the concept of the microbial loop. Dissolved Org matter lacustrine Ecosyst 73:107-114. https://doi.org/10.1007/978-94-011-2474-4_8

54. Yu SJ, Ha SR, Hwang JY, Kim CS (2003) Characteristics of Aqueous Organic Matter and Disinfection By-products (DBPs) Formation Potentials in Geum River. J Korean Soc Water Environ 19:707-713 (In Korean)

55. Zhao Z, Liu G, Liu Q, Huang C, Li H (2018) Studies on the spatiotemporal variability of river water quality and its relationships with soil and precipitation: a case study of the Mun River Basin in Thailand. Int J Environ Res Public Health 15(11):2466. https://doi.org/10.3390/ijerph15112466

56. Zsolnay A, Baigar E, Jimenez M, Steinweg B, Saccomandi F (1999) Differentiating with fluorescence spectroscopy the sources of dissolved organic matter in soils subjected to drying. Chemosphere 38(1):45-50. https://doi.org/10.1016/S0045-6535(98)00166-0

\section{Figures}




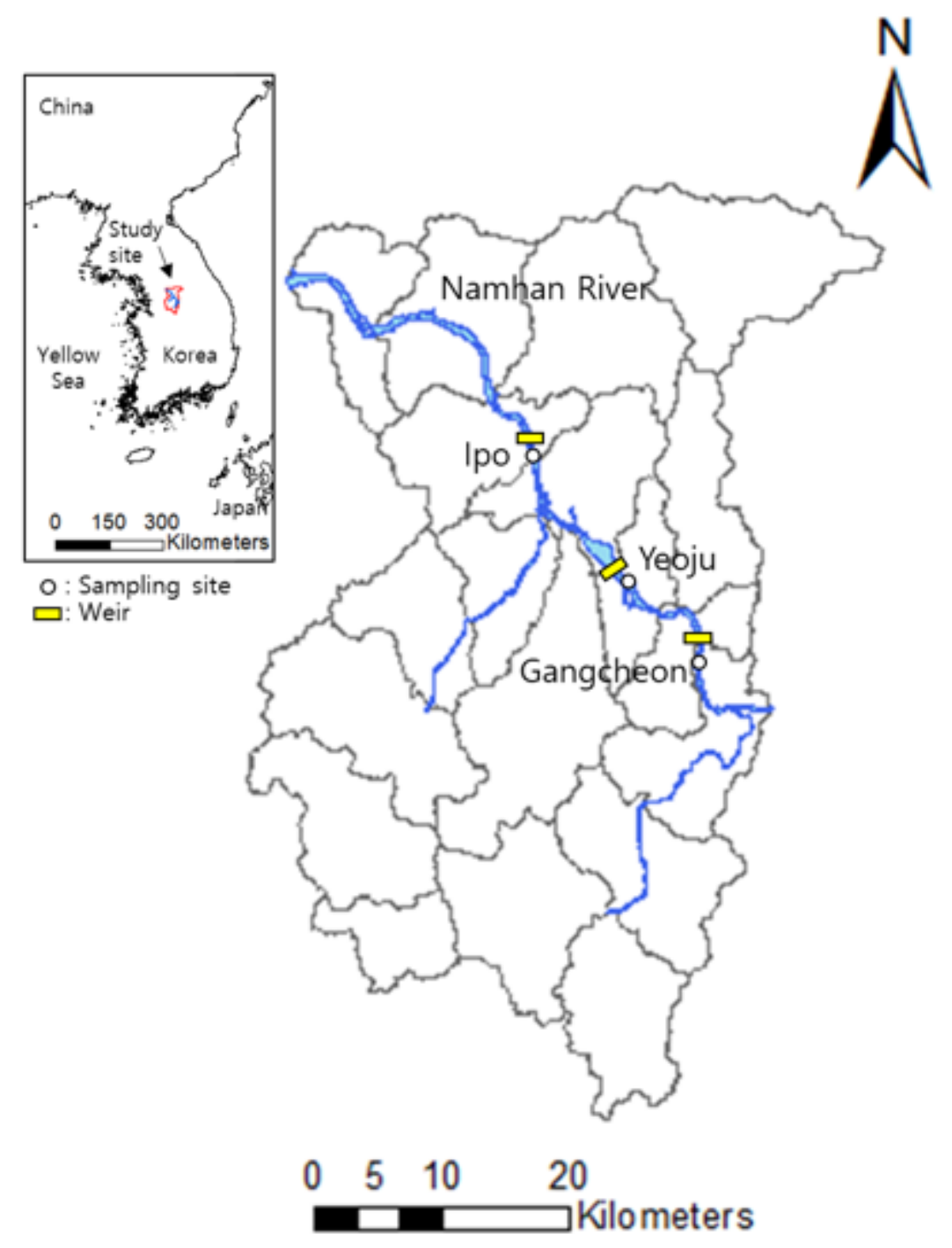

\section{Figure 1}

Map of sampling location in the Namhan River basin, Korea. Detailed sampling site indications are provided (Gangcheon, Yeoju and Ipo weir) 

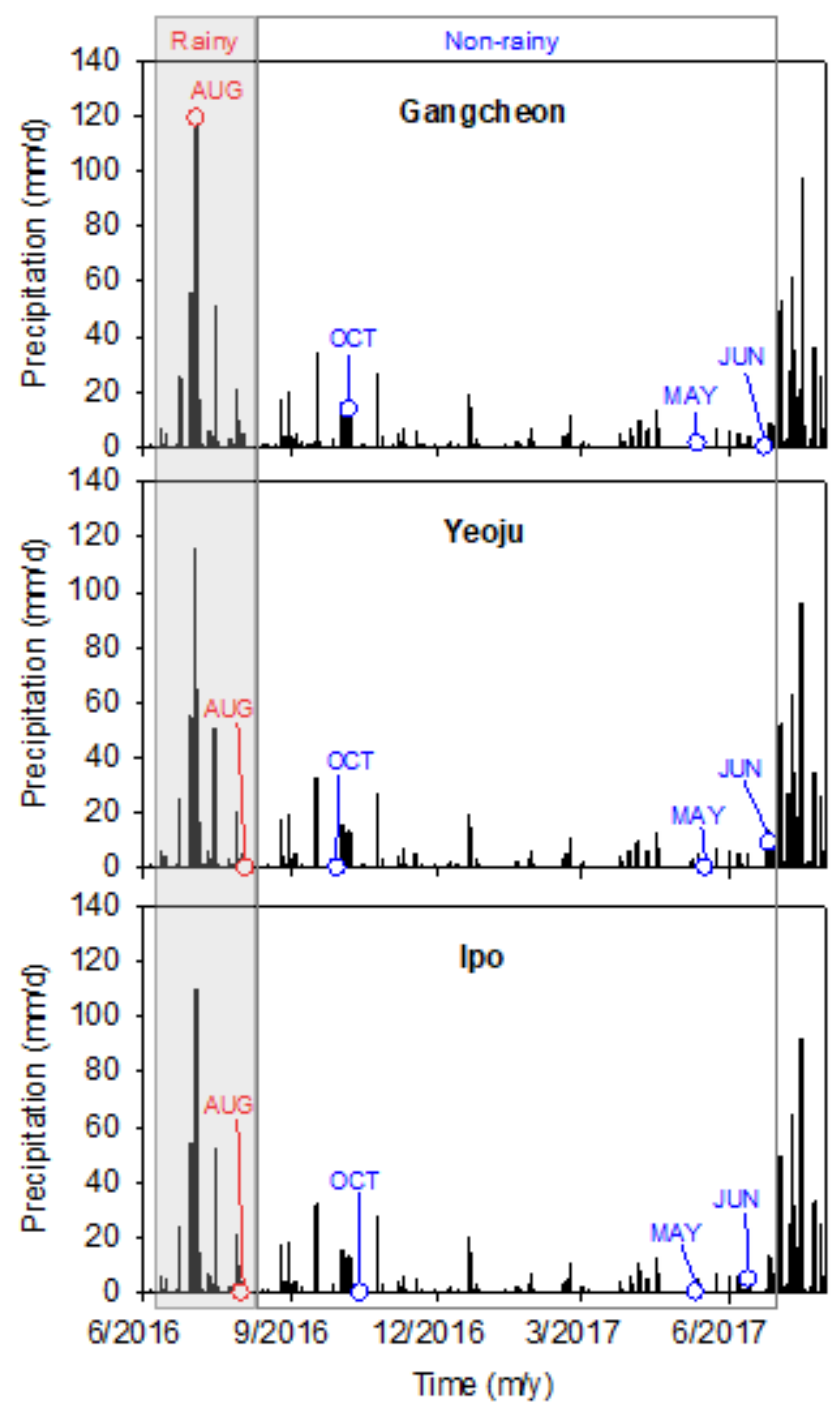

Figure 2

Precipitation during the sampling period 

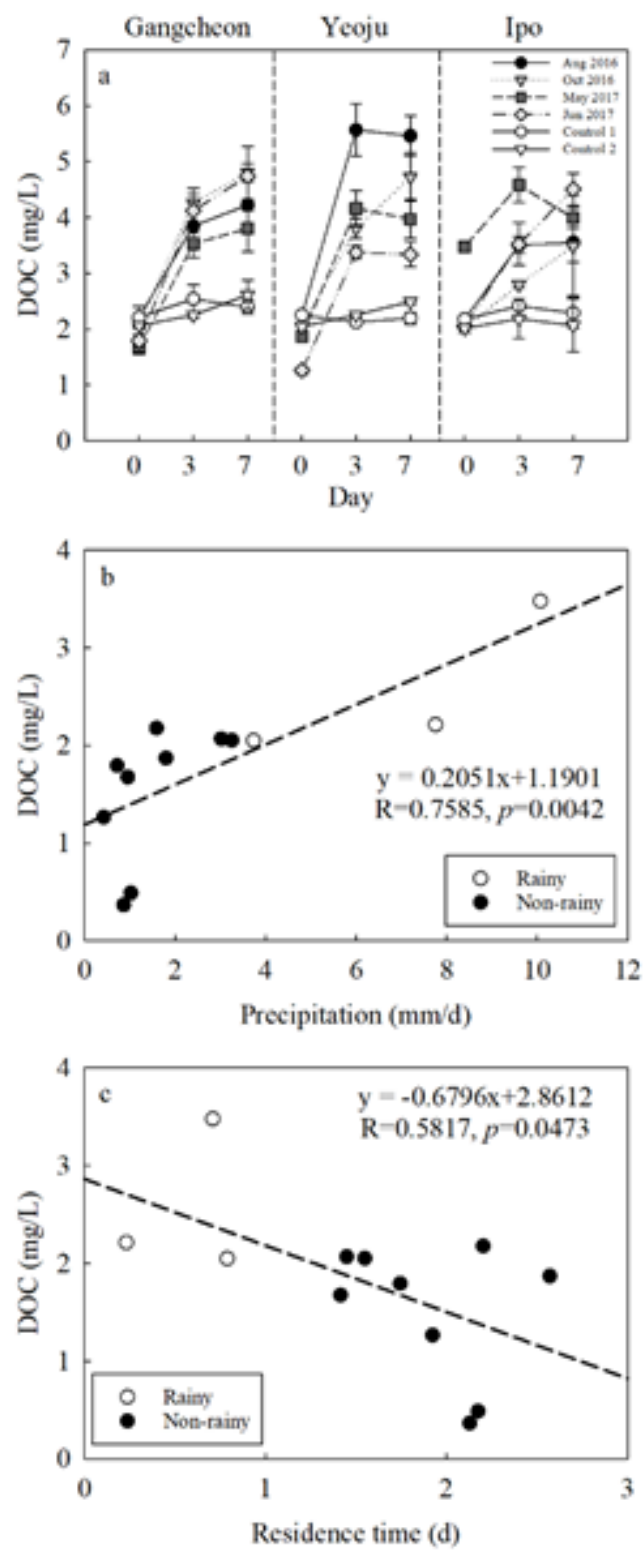

\section{Figure 3}

(a) Changes in the DOC concentration over the incubation (7 days) in the samples obtained 2016-2017 and two controls during the incubation period and correlation between (b) precipitation, (c) residence time and initial DOC concentration 

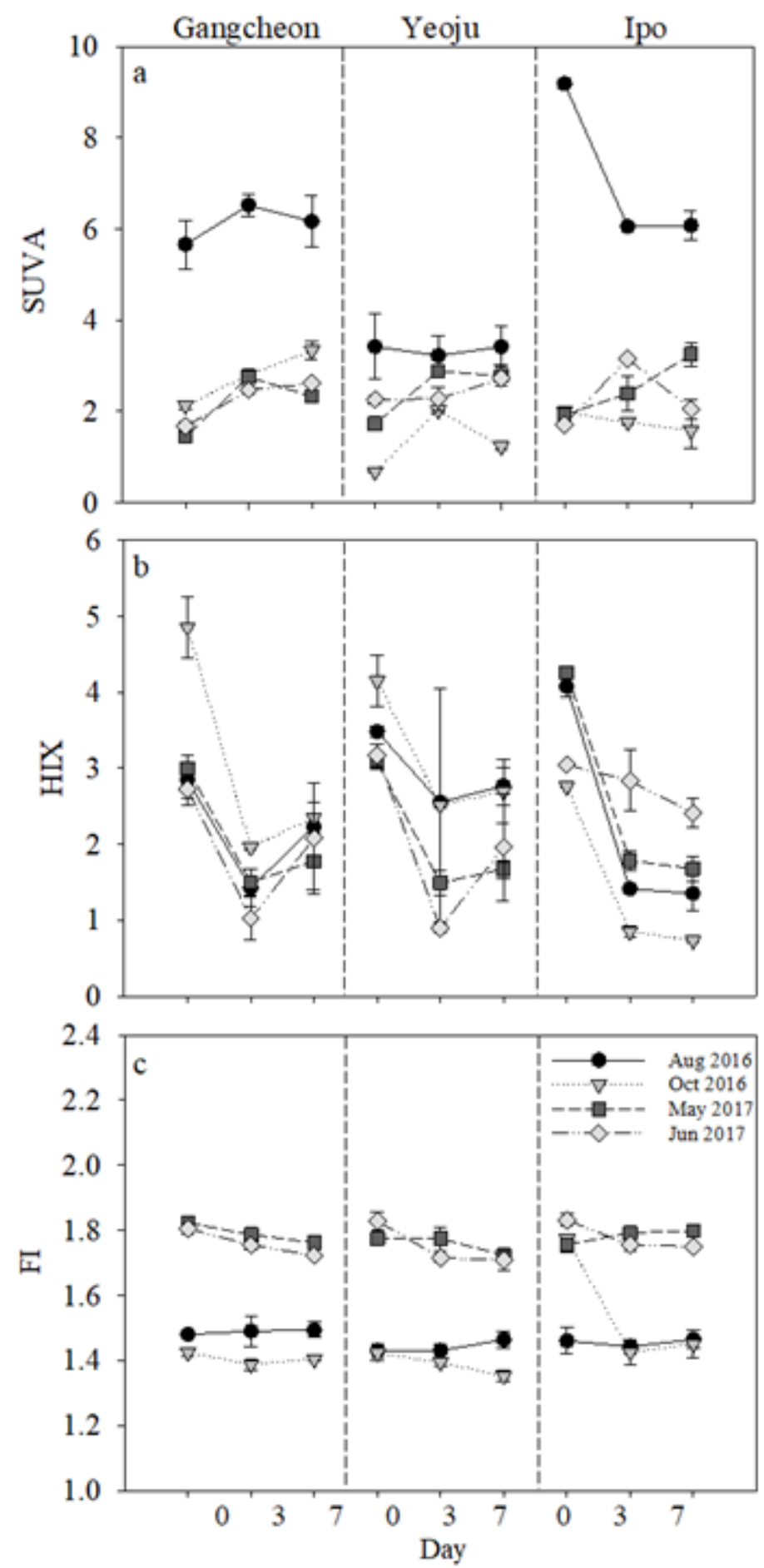

Figure 4

Changes in the optical properties of DOM: (a) $\mathrm{SUVA}_{254}$ (b) HIX, and (c) FI during the incubation period 

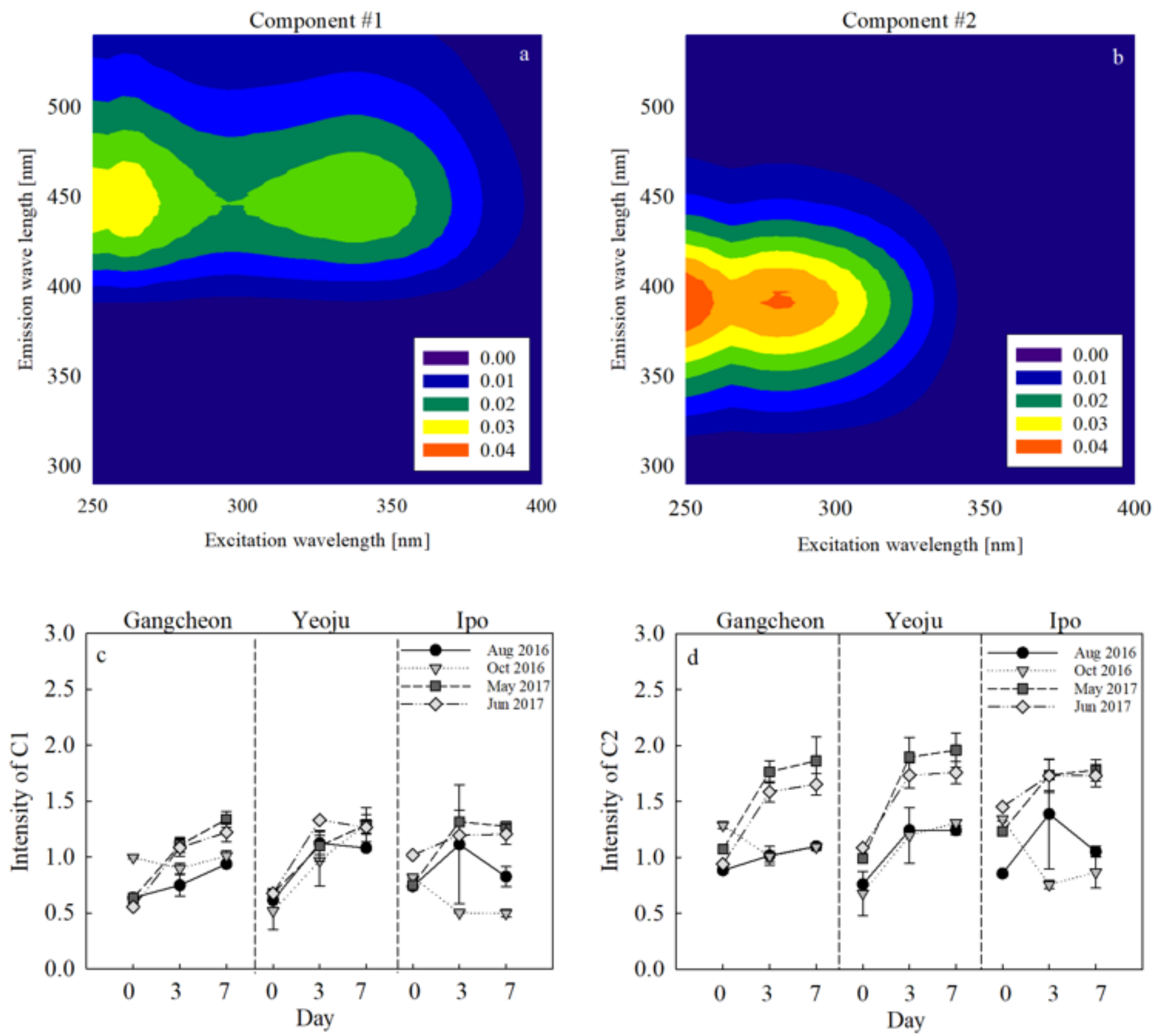

Figure 5

Contour plots of (a) Component 1 (terrestrial humic-like components) and (b) Component 2 (terrestrial tryptophan-like components; higher intensities in red). Changes in the intensity of PARAFAC components: (c) humic-like component (C1) and (d) tryptophan-like component (C2) 


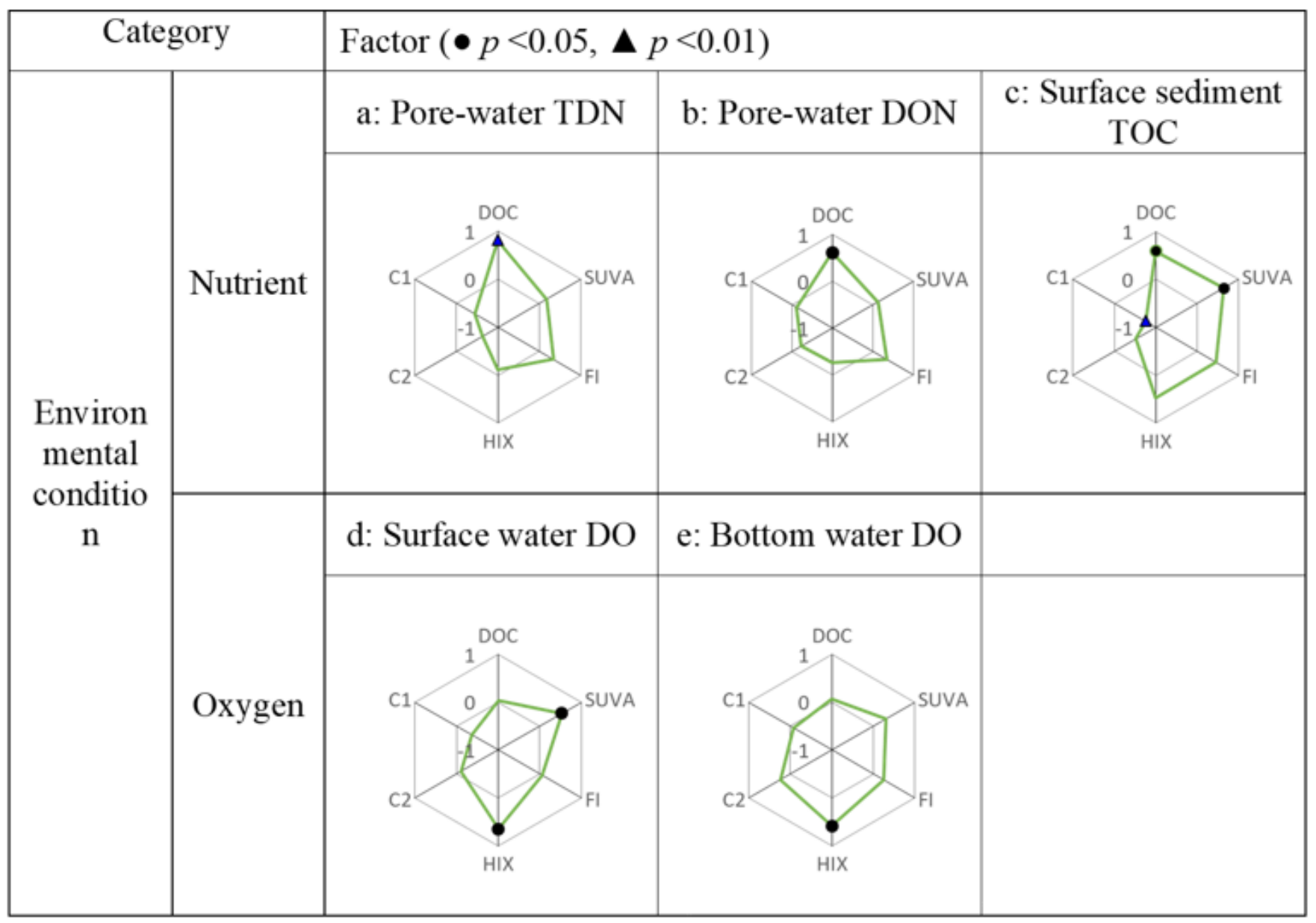

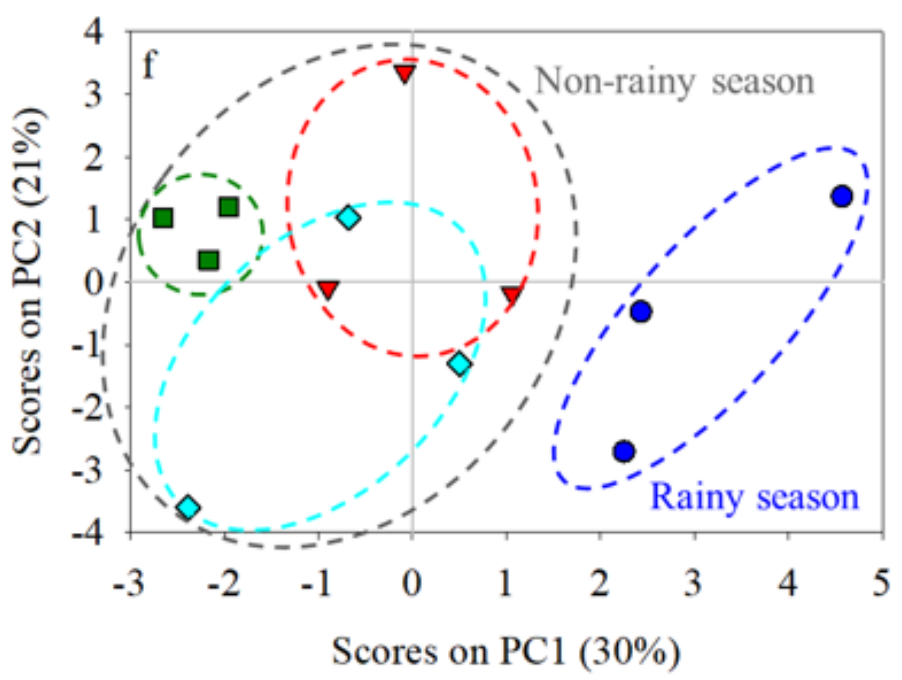

- Aug $\nabla$ Oct $\square$ May $\diamond$ Jun

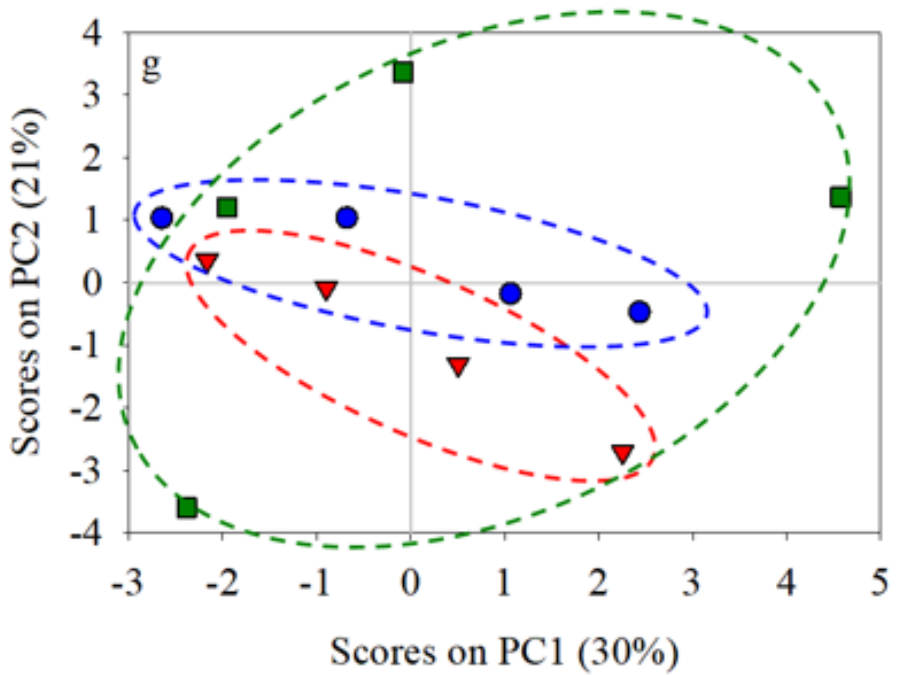

- Gangcheon $\nabla$ Yeoju $\square$ Ipo

\section{Figure 6}

Wind-rose diagrams of the correlation between DOM properties (DOC release rate, SUVA $254, \mathrm{FI}, \mathrm{HIX}$, humiclike [C1] and tryptophan-like compounds [C2]) and environmental factors (pore-water TDN, DON, surface sediment TOC, surface and bottom water DO). The value of the graph means Pearson's R, and the circles and triangles show that there is a significant correlation when the $P$ value is less than 0.05 and 0.01 , respectively. Score plots for PC1 and PC2 as a function of sampling (f) time and (g) location 
Page 25/25 